\title{
電磁力を用いた運動量交換型衝撃吸収ダンパによる衝撃振動の低減
}

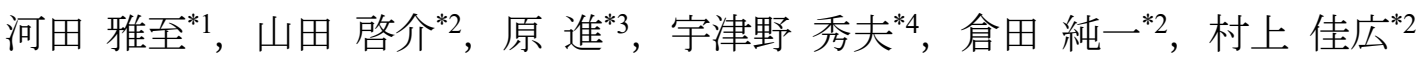

\section{Reduction of impact vibration by momentum exchange impact damper}

\section{using electromagnetic force}

\author{
Masashi KAWATA $^{* 1}$, Keisuke YAMADA ${ }^{* 2}$, Susumu HARA ${ }^{* 3}$, Hideo UTSUNO ${ }^{* 4}$, Junichi KURATA ${ }^{* 2}$, \\ and Yoshihiro MURAKAMI ${ }^{* 2}$ \\ ${ }^{* 1}$ Department of Mechanical Engineering, Kansai University, \\ 3-3-35 Yamate-cho, Suita-shi, Osaka 564-8680, Japan \\ ${ }^{*},{ }^{* 4}$ Faculty of Engineering Science, Kansai University, \\ 3-3-35 Yamate-cho, Suita-shi, Osaka 564-8680, Japan \\ ${ }^{* 3}$ Department of Aerospace Engineering, Nagoya University, \\ Furo-cho, Chikusa-ku, Nagoya-shi, Aichi 464-8603, Japan
}

Received: 5 December 2018; Revised: 21 January 2019; Accepted: 17 March 2019

\begin{abstract}
In this paper, we proposed a momentum exchange impact damper using a solenoidal coil and a capacitor to suppress impact vibration. Noise and vibration generated by forging machines and press machines have been a serious problem. In order to reduce impact vibration, the momentum exchange impact damper has been studied by many researchers. The basic principle of this damper is based on the momentum transfer during the collisions of three rigid bodies. This impact damper is the most effective when the mass of the damper is equal to the mass of the bed of the forging machine. However, the mass of the damper is usually smaller than the mass of the bed for practical use. In this study, this problem was solved by using a solenoidal coil and a capacitor. The electrical charge stored in the capacitor flows through the solenoidal coil when the impact damper passes through the solenoidal coil using a switch. The electromagnetic force is generated by the electrical current, and the electromagnetic force absorbs the kinetic energy of the host structure. The effectiveness of the proposed method was verified through simulations and experiments.
\end{abstract}

Keywords : Damping, Impact vibration, Vibration control, Momentum exchange, Electromagnetic force

\section{1. 緒言}

鍛造機械やプレス機械では，加工の際に衝撃的な力が加わり，振動や騒音が発生する。これが周辺地域への振 動公害や作業者の聴覚障害などの問題を引き起こしている. そこで，主系に動吸振器を設置する研究が行われた (Webster and Vaicaitis, 1992). これは主系に減衰を付加できるが，衝撃的な加振で問題となる過渡応答の最初の最 大振幅值を低減できない問題があった。 また，能動制振も検討されているが，センサやアクチュエータが必要と なり，機構が複雑化する(Tanaka and Kikushima, 1989). そこで, 衝撃振動の最初に現れる最大振幅を低減でき，か つ制御不要で簡便な制振方法として運動量交換型衝撃吸収ダンパが提案された(門馬他，2002; 河内他，2004; Son et al., 2006, 2008). 鍛造機械やプレス機械以外にも，重量床衝撃音の低減を目指した研究(門馬他，2002；河内他， 2004)や, 月惑星探査機の着陸時のバウンドの制御を目的として運動量交換型衝撃吸収ダンパを用いる研究が行わ れている(原他，2012).

\footnotetext{
No.18-00485 [DOI:10.1299/transjsme.18-00485], J-STAGE Advance Publication date : 26 March, 2019

${ }^{* 1}$ 学生員, 関西大学大学院 理工学研究科 (广564-8680 大阪府吹田市山手町 3-3-35)

*2 正員, 関西大学システム理工学部

*3 正員, 名古屋大学大学院工学研究科 ( $4464-8603$ 愛知県名古屋市千種区不老町)

*4 正員, フェロー, 関西大学システム理工学部

E-mail of corresponding author: yamadak@kansai-u.ac.jp
} 
受動型の運動量交換型衝撃吸収ダンパは，玉突きの原理を応用した方法であり，衝撃により主系に加わる力積 を瞬時に衝撃吸収ダンパが運動量として受けとることで, 主系の過渡応答の最初の最大振幅值を抑えることがで きる. 制振対象に対する運動量交換型衝撃吸収ダンパの質点の質量比が 1 に近いほど衝撃低減効果が高く, 質量 比が小さくなると十分な低減効果が得られない問題がある(Son et al., 2006, 2008). そこで, Son らは受動型の運動 量交換型衝撃吸収ダンパにアクチュエータを組込み, 線形最適制御を適用することで能動的に制振性能を向上さ せる方法を提案した(Son et al., 2010). この方法は受動型に比べて性能は高いが，コントローラによる制御が必要 である，そこで，本研究ではディジタルコントローラ不要の簡易な制振装置として，受動型の運動量交換型衝撃 吸収ダンパに電磁力発生用のソレノイドコイルとコンデンサを組込み, 電磁力を発生させて運動量の交換を促進 し, 主系の運動エネルギを吸収することで, 小さい質量比でも十分な衝撃低減効果が得られる方法を提案する. 本手法ではコンデンサにあらかじめ電荷を蓄えておき, 衝撃が加わると同時にスイッチでソレノイドコイルと電 気的に接続して電流を流すことで電磁力を発生させる.コンデンサに電荷を蓄えるために外部のエネルギを注入 するが，スイッチで電気的に接続した後は自由振動であり，制御は不要である，電磁力を発生させるソレノイド コイルの部分では, コイルガンと同様に，スイッチを用いて電磁力の発生を制御する，そして，インダクタンス と静電容量で決まる電気系の固有振動数を高く設定することで, 短時間で運動量交換を促進する. また，スイッ チをオンにする代わりにサイリスタで電流を流し，スイッチをオフにする代わりにサイリスタ内のダイオードを 用いて逆流を阻止することで電流を止める. 本研究では提案手法の基礎的な知見を得ることを目的とし, 制振対 象がインパルス加振される場合について，理論解析を行う。シミュレーションと実験を通して提案手法の有効性 と理論解析の妥当性を確認する.

\section{2. 運動量交換型衝撃吸収ダンパの原理}

運動量交換型衝撃吸収ダンパは，玉突きの原理を応用した衝撃振動低減装置である．図 1 に示すような，同一 直線上にある三つの質点について考える(Ceanga and Hurmuzlu, 2001). 質点 1，2 の質量はどちらも $m_{1}$ とする. 衝 撃源の質点の質量 $m$ は $m_{1}$ より小さいとする. また, 質点間の衝突は完全弾性衝突とする. はじめに, 質点 1,2 が接触した状態で静止しており, 衝撃源が速度 $v$ で質点 1 に衝突したとする. すると, 質点 1 は静止したままで 質点 2 が衝撃源の衝突前の速度 $v$ よりも小さい速度 $\left[2 m /\left(m+m_{1}\right)\right] v$ で動き出す. 本研究では, 質点 1 を制振対象, 質点 2 を衝撃吸収ダンパとして考える.この手法は衝撃により制振対象に加わる力積を瞬時に衝撃吸収ダンパが 運動量として受けとることで，主系の過渡応答の最大振幅值を抑えることができる.

つぎに，質点 2 の質量 $m_{2}$ が質点 1 の質量 $m_{1}$ よりも小さい場合について，同様の衝突を行った場合を考える. これは, 制振対象が大型で, それよりも質量の小さい衝撃吸収ダンパしか設置できない場合に相当する.ここで, 図 2 のように衝撃源が質点 1 に衝突したとする，それぞれの衝突において運動量は保存され，いずれの衝突にお いても反発係数は 1 であるので, 衝突後の衝撃源, 物体 1，2 の速度はそれぞれ次式となる.

$$
\begin{aligned}
& v^{\prime}=\frac{m-m_{1}}{m+m_{1}} v<0 \\
& v_{1}^{\prime}=\frac{2 m\left(m_{1}-m_{2}\right)}{\left(m+m_{1}\right)\left(m_{1}+m_{2}\right)} v>0 \\
& v_{2}=\frac{4 m m_{1}}{\left(m+m_{1}\right)\left(m_{1}+m_{2}\right)} v
\end{aligned}
$$

ここで， $v^{\prime}$ は衝撃源の衝突後の速度， $v_{1}^{\prime}(>0)$ は質点 1 の質点 2 との衝突後の速度， $v_{2}$ は質点 2 の衝突後の速度 である. なお, 速度は右向きを正の方向とした。 このとき, 衝突によって, 質点 1 が衝撃源から受ける力積が, さらに質点 2 の運動量に交換される. しかし, 式(2)より質点 2 の質量が質点 1 の質量よりも小さい場合には, 制 振対象の衝突後の速度 $v_{1}^{\prime}$ をゼロにすることはできない. 


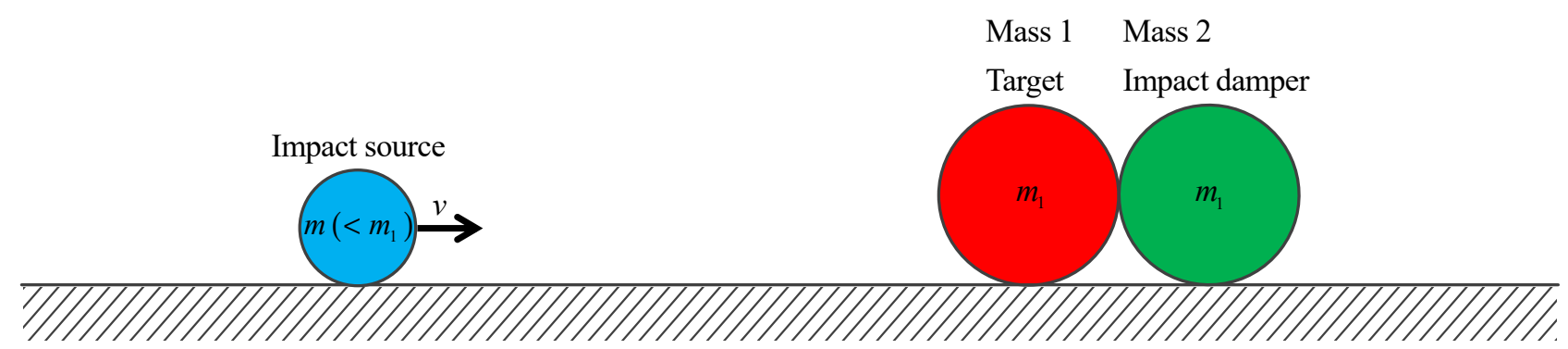

Fig. 1 Collisions of three point masses when the point mass 1 and point mass 2 have the same mass $\left(m_{1}>m\right)$. In this case, the velocity of the point mass 1 is zero after the collision.

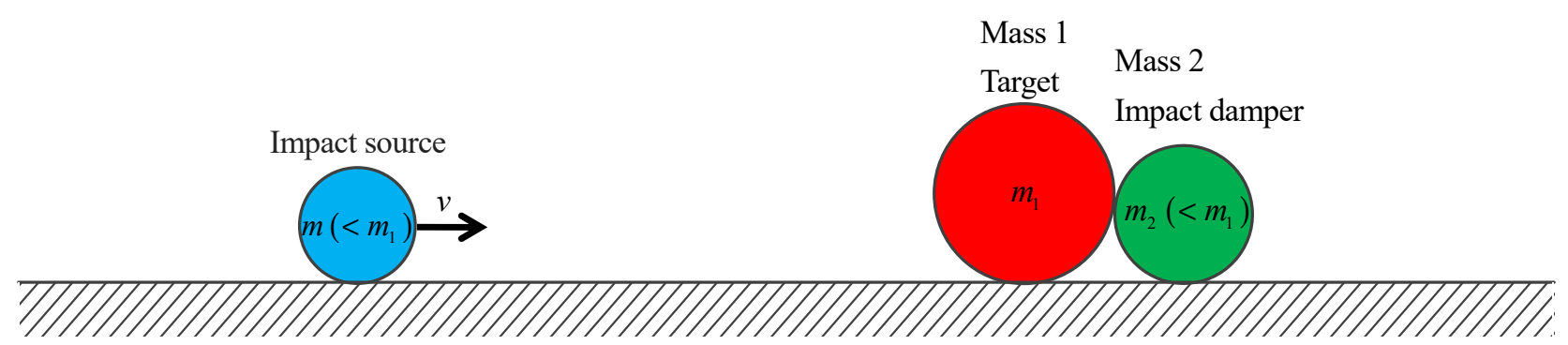

Fig. 2 Collisions of three point masses when the three point masses have different masses $\left(m_{1}>m_{2}\right)$. In this case, the velocity of the point mass 1 is not zero after the collision.

\section{3. 理 論解析}

\section{$3 \cdot 1$ 解析モデル}

図 3 に本研究の解析モデルと本研究で用いる回路図を示す。この解析モデルでは制振対象の台に相当する質量 $m_{1}$ の剛体が，ばね定数 $k_{1} / 2$ のばね二つで両端を支えられている．ただし，本研究では剛体の鉛直方向の自由度 のみを考慮するため, 実質的には質点として考える. 衝撃吸収ダンパとして質量 $m_{2}$ の質点が台の下部に設置され ており，これはばねとダッシュポットで支えられている．本研究では，より大きな電磁力を得るために運動量交 換型衝撃吸収ダンパの質点部分に永久磁石を用いる. また，台にソレノイドコイルが剛結合されている. この方 法は衝撃時の受動的な運動量交換に加え, 衝撃後にソレノイドコイルがダンパの質点を吸引する電磁力を利用し て，運動量の交換を促進し，台の運動エネルギを吸収させ，衝撃低減効果を高めることを目的としている．加振 後，短時間で主系の運動エネルギを吸収させることで過渡応答の最初に現れる主系の最大变位を抑える．図 3 の ように主系の変位を $x_{1}$, 衝撃吸収ダンパの変位を $x_{2}$ とする. $x_{1}$ と $x_{2}$ はそれぞれ衝撃力が加わる前のつり合いの 位置を原点とし, 鉛直上向きを正の方向とする. また, 台に与えられる衝撃力は $f$ とし, 力の正の方向も上向き とする．質量 $m_{2}$ の質点を支えるばねのばね定数を $k_{2}$, ダッシュポットの減衰係数を $d_{2}$ とする. ただし，ダッシ ユポットは $\dot{x}_{2}>0$ のときにだけ効く片効きとする.これは衝撃を与えた直後に衝撃吸収ダンパが下向きに動いて いる間は，ダッシュポットが働くとダッシュポットを通じて床下に力が伝達するため，ダッシュポットが効かな いようにする必要があり，衝撃吸収ダンパが上に戻る間は，衝撃吸収ダンパが主系に強く当たらないようにダッ シュポットで減衰を与えてゆっくり戻す必要があるためである.

図 3 の回路図において，提案手法では衝撃力が加わる前にスイッチ 1 をオン，スイッチ 2 をオフにしてコンデ ンサに電荷を蓄え, 十分に時間が経ってからスイッチ 1 もオフにして, 衝撃が加わった際にスイッチ 2 をオンに してソレノイドコイルに電流を流す。なお， 5 章の実験ではスイッチ 2 とダイオードの代わりにサイリスタを用 いた. 直流電源の電圧を $V_{\mathrm{DC}}$, コンデンサの静電容量を $C_{3}$, ソレノイドコイルのインダクタンスを $L_{3}$ と デンサとコイルの内部抵抗を合わせて抵抗值 $R_{3}$ の抵抗器でモデル化した. ここで, LRC 回路における電流 $\dot{q}$ の正 の向きを時計回りとする. また, 主系の変位を増やす方向に電磁力が働かないようにするために, ダイオードで 電流の逆流を阻止する. 


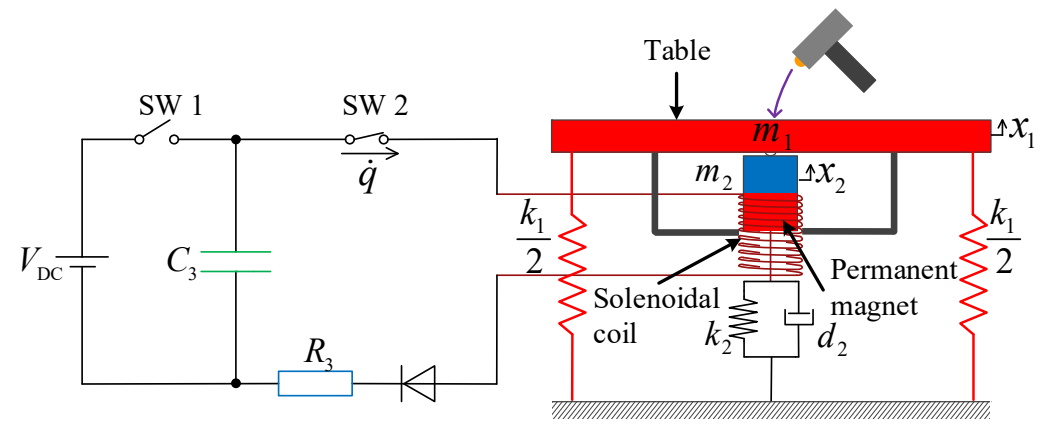

Fig. 3 Analytical model of the proposed method and circuit diagram of the electrical circuit coupled to the solenoidal coil. The electrical charge stored in the capacitor flows through the solenoidal coil when the impact damper passes through the solenoidal coil using the switch 2.

\section{$3 \cdot 2$ 電磁力の導出}

本研究では, 図 3 のように永久磁石の片側の磁極がソレノイドコイル内に入っている状態で使用することとす る. 簡単のため, ソレノイドコイル中の磁極をソレノイドコイルの中心軸上にある点磁荷でモデル化する.また， ソレノイドコイル内の磁場は一様と考える. 図 4 に電磁力を導出するための解析モデルを示す. ソレノイドコイ ルが内部の中心軸上に作る磁場 $H$ は,

$$
H=-\frac{N \dot{q}}{l}
$$

と表せる. ただし. 磁場も上向きを正の方向とした。ここで， $l, N$ はそれぞれソレノイドコイルの長さ，巻き数 である.また，磁石に上向きに加えられる電磁力 $f_{\mathrm{C}}$ は

$$
f_{\mathrm{C}}=\sigma H
$$

と表される．ここで， $\sigma$ は片側の磁極に相当する点磁荷の磁荷である.図 3 のように磁石の $\mathrm{N}$ 極がコイルの内部 にある場合は $\sigma$ の值は正である. なお，反力としてコイルにも下向きに電磁力 $f_{\mathrm{C}}$ が働く. 式(4)を式(5)に代入す ると, 電磁力 $f_{\mathrm{C}}$ は

$$
f_{\mathrm{C}}=-\frac{N \sigma \dot{q}}{l}
$$

となり, 電流 $\dot{q}$ に比例する. 本研究では $\sigma$ と $\dot{q}$ はともに正であるので, $f_{\mathrm{C}}$ は負となる. すなわち, 永久磁石がコ イルに吸い込まれる方向に力が働く.

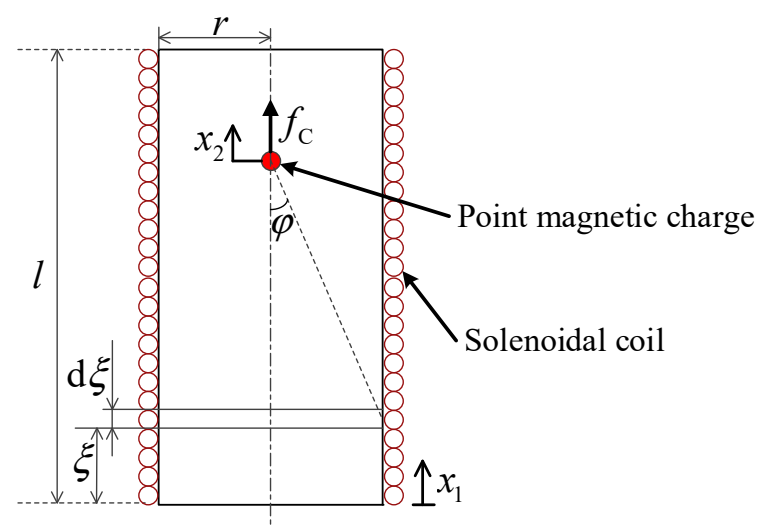

Fig. 4 Analytical model to derive the electromagnetic force applied to the solenoidal coil and permanent magnet. The permanent magnet is modeled by a magnetic monopole in the solenoidal coil. 


\section{$3 \cdot 3$ 運動方程式}

主系がインパルス加振され, 衝撃吸収ダンパが主系から離れた後の主系と衝撃吸収ダンパの運動方程式は, そ れぞれ次のようになる.ただし，ダッシュポットは $\dot{x}_{2}>0$ のときにだけ効く片効きとする.

$$
\begin{aligned}
& m_{1} \ddot{x}_{1}+k_{1} x_{1}=\frac{N \sigma \dot{q}}{l} \\
& m_{2} \ddot{x}_{2}+d_{2} \dot{x}_{2}+k_{2} x_{2}=-\frac{N \sigma \dot{q}}{l}
\end{aligned}
$$

なお，インパルス加振によって，主系と衝撃吸収ダンパの質点に初速度 $\dot{x}_{1}(0) ， \dot{x}_{2}(0)$ が与えられるが，それ らはそれぞれ

$$
\begin{aligned}
& \dot{x}_{1}(0)=\frac{m_{1}-m_{2}}{m_{1}\left(m_{1}+m_{2}\right)} F_{\mathrm{m}} \\
& \dot{x}_{2}(0)=\frac{2}{m_{1}+m_{2}} F_{\mathrm{m}}
\end{aligned}
$$

である.ここで， $F_{\mathrm{m}}(<0)$ は衝撃源が主系に与える力積である. 初期変位はどちらもゼロである.

\section{$3 \cdot 4$ 回路方程式}

図 4 のソレノイドコイルの下面から距離 $\xi$ の位置にある一巻きの円形コイルを考える. 一巻きの円形コイルを 貫く磁束 $\Phi$ は

$$
\Phi=-\frac{1}{2} \sigma(1-\cos \varphi)
$$

と表される(砂川，1987). ただし，磁束 $\Phi$ も向きを正の方向とした．ここで， $\varphi$ は円形コイルの中心軸に対し て点磁荷と一巻きの円形コイルの円周を結んだ線分がな寸角であり，磁束 $\Phi$ は

$$
\Phi=-\frac{1}{2} \sigma\left[1-\frac{l_{\mathrm{x}}+x_{2}-x_{1}-\xi}{\sqrt{r^{2}+\left(l_{\mathrm{x}}+x_{2}-x_{1}-\xi\right)^{2}}}\right]
$$

となる.ここで， $r$ は円形コイルの半径， $l_{\mathrm{x}}$ は主系の変位 $x_{1}$ と衝撃吸収ダンパの変位 $x_{2}$ の原点間の距離である. なお, 主系の変位 $x_{1}$ の原点は加振前のソレノイドコイルの下面に, ダンパの変位 $x_{2}$ の原点は加振前の $\mathrm{N}$ 極の磁 荷の位置にした。

つぎに, ソレノイドコイルはこの円形コイルの積み重ねと考えて, ソレノイドコイルの磁束を求める. 図 4 に おけるソレノイドコイルの微小部分の長さ $\mathrm{d} \xi$ の巻き数は $(N / l) \mathrm{d} \xi$ であるため, この微小部分の磁束 $\mathrm{d} \Phi$ は,

$$
\mathrm{d} \Phi=-\frac{N \sigma}{2 l}\left[1-\frac{l_{\mathrm{x}}+x_{2}-x_{1}-\xi}{\sqrt{r^{2}+\left(l_{\mathrm{x}}+x_{2}-x_{1}-\xi\right)^{2}}}\right] \mathrm{d} \xi
$$

となる(高橋, 1965 ; 竹山，1944). これをソレノイドコイルの全長 $l$ で積分すると磁束 $\Phi$ が,

$$
\Phi=\int_{0}^{l} \mathrm{~d} \Phi=-\frac{N \sigma}{2 l}\left[l+\sqrt{r^{2}+\left(l_{\mathrm{x}}+x_{2}-x_{1}-l\right)^{2}}-\sqrt{r^{2}+\left(l_{\mathrm{x}}+x_{2}-x_{1}\right)^{2}}\right]
$$

と求まる.よって, 誘導起電力 $v_{\mathrm{C}}$ は,

$$
v_{\mathrm{C}}=\frac{\mathrm{d} \Phi}{\mathrm{d} t}=-\frac{N \sigma}{2 l}\left[\frac{l_{\mathrm{x}}+x_{2}-x_{1}-l}{\sqrt{r^{2}+\left(l_{\mathrm{x}}+x_{2}-x_{1}-l\right)^{2}}}-\frac{l_{\mathrm{x}}+x_{2}-x_{1}}{\sqrt{r^{2}+\left(l_{\mathrm{x}}+x_{2}-x_{1}\right)^{2}}}\right]\left(\dot{x}_{2}-\dot{x}_{1}\right)
$$


と表される.ここで，ソレノイドコイルの半径 $r$ が $l_{x}+x_{2}-x_{1}$ に比べて十分小さく, ソレノイドコイルの長さ $l$ が $l_{\mathrm{x}}+x_{2}-x_{1}$ に比べて十分に大きいとすると, 式(15)は次式となる.

$$
v_{\mathrm{C}}=\frac{N \sigma}{l}\left(\dot{x}_{2}-\dot{x}_{1}\right)
$$

以上より，スイッチ2だけがオンのときの回路方程式は,

$$
L_{3} \ddot{q}+R_{3} \dot{q}+\frac{1}{C_{3}} q=\frac{N \sigma}{l}\left(\dot{x}_{2}-\dot{x}_{1}\right)
$$

となる。

\section{$3 \cdot 5$ 等価機械モデル}

スイッチ 1 はオフで, スイッチ 2 がオンの状態の全系の等価機械モデルを求める.すなわち, 衝撃により質量 $m_{2}$ の質点が台から離れた後を考える. 式(7)，(8)，(17)より，本研究の解析モデルの支配方程式は次式のように表せ る.

$$
\begin{aligned}
& m_{1} \ddot{x}_{1}+k_{1} x_{1}=\alpha \dot{q} \\
& m_{2} \ddot{x}_{2}+d_{2} \dot{x}_{2}+k_{2} x_{2}=-\alpha \dot{q} \\
& L_{3} \ddot{q}+R_{3} \dot{q}+\frac{1}{C_{3}} q=\alpha\left(\dot{x}_{2}-\dot{x}_{1}\right)=v_{\mathrm{C}}
\end{aligned}
$$

ここで, 比例定数 $\alpha$ は電気系の影響係数であり, 次式で定義される.

$$
\alpha=\frac{N \sigma}{l}
$$

式(20)より，

$$
\begin{aligned}
& \ddot{q}=\frac{v_{\mathrm{C}}-v_{3}}{L_{3}}, \quad v_{3}=R_{3} \dot{q}+\frac{1}{C_{3}} q \\
& \dot{q}=\frac{v_{3}-v_{4}}{R_{3}}, \quad v_{4}=\frac{1}{C_{3}} q
\end{aligned}
$$

と書ける. $v_{3}=-\alpha \dot{x}_{3}, \quad v_{4}=-\alpha \dot{x}_{4}$ を導入すると，

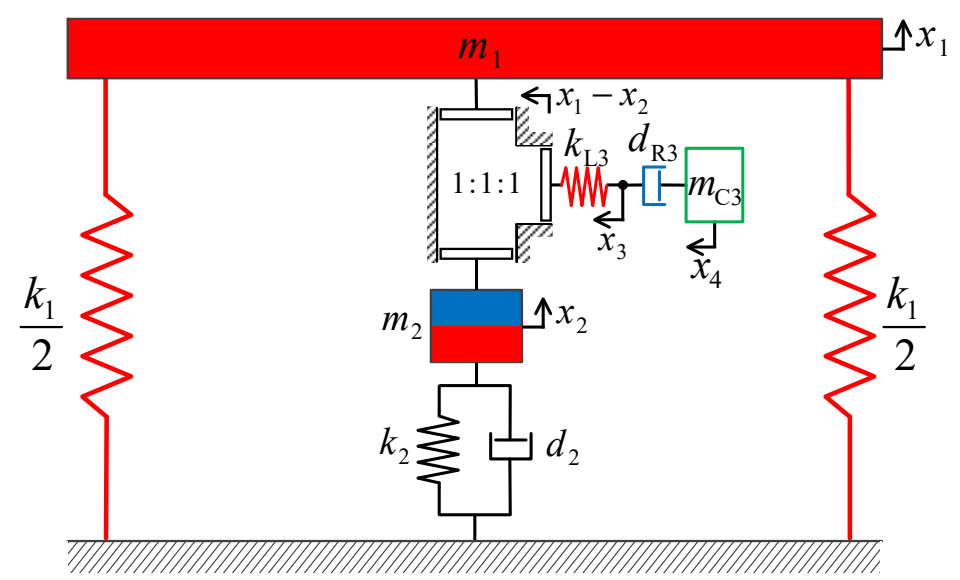

Fig. 5 Equivalent mechanical model of the proposed method. This model is derived by Eqs. (25)-(28). The inductor corresponds to the spring, the resistor corresponds to the dashpot and the capacitor corresponds to the mass, respectively. 


$$
\dot{q}=\frac{\alpha}{L_{3}}\left(x_{2}-x_{1}+x_{3}\right)=\frac{\alpha}{R_{3}}\left(\dot{x}_{4}-\dot{x}_{3}\right)=-\alpha C_{3} \ddot{x}_{4}
$$

という関係が得られる。式(18)，(19)，(24)より，運動方程式と回路方程式はそれぞれ次式に書きかえられる.

$$
\begin{array}{ll} 
& m_{1} \ddot{x}_{1}+k_{1} x_{1}+k_{\mathrm{L} 3}\left(x_{1}-x_{2}-x_{3}\right)=0 \\
& m_{2} \ddot{x}_{2}+d_{2} \dot{x}_{2}+k_{2} x_{2}+k_{\mathrm{L} 3}\left(x_{2}-x_{1}+x_{3}\right)=0 \\
& m_{\mathrm{C} 3} \ddot{x}_{4}+d_{\mathrm{R} 3}\left(\dot{x}_{4}-\dot{x}_{3}\right)=0 \\
& d_{\mathrm{R} 3}\left(\dot{x}_{3}-\dot{x}_{4}\right)+k_{\mathrm{L} 3}\left(x_{3}-x_{1}+x_{2}\right)=0 \\
こ こ て ゙, \quad m_{\mathrm{C} 3}, \quad d_{\mathrm{R} 3}, \quad k_{\mathrm{L} 3} \text { は, それぞれ } \\
m_{\mathrm{C} 3}=\alpha^{2} C_{3} \\
d_{\mathrm{R} 3}=\frac{\alpha^{2}}{R_{3}} \\
k_{\mathrm{L} 3}=\frac{\alpha^{2}}{L_{3}}
\end{array}
$$

である．式(25)-(28)より，本研究の解析モデルは図 5 に示す等価機械モデルで表すことができる. 図 5 の等価機 械モデルにおける 3 つのピストンの面積の比は 1:1:1 で, シリンダは空間に固定されており，シリンダ内の体積 は一定である，ここで，コンデンサに初期電荷を蓄えることは式(22)，(23)，(27)より， $\dot{x}_{3}$ と $\dot{x}_{4}$ に初速度を与える ことと等価である.ばね定数 $k_{\mathrm{L} 3}$ と減衰係数 $d_{\mathrm{R} 3}$ は，瞬時に大きな力を伝えるために，大きな值でなければならな い.

\section{4. シミュレーション}

\section{$4 \cdot 1$ 比較に用いる 4 つのモデル}

図 6 にシミュレーションで用いた 4 つのモデルを示す.ここで，(a)は主系のみの場合，(b)は(a)において主系の 質量を衝撃吸収ダンパの質量分だけ大きくした場合，(c)は従来の運動量交換型衝撃吸収ダンパの場合(門馬他， 2002; 河内他, 2004; Son et al., 2006, 2008), (d)は提案手法の場合である. 今回は簡単のため, 衝撃吸収ダンパを支 持しているばねのばね定数 $k_{2}$ とダッシュポットの減衰定数 $d_{2}$ はどちらもゼロとしてシミュレーションを行った.

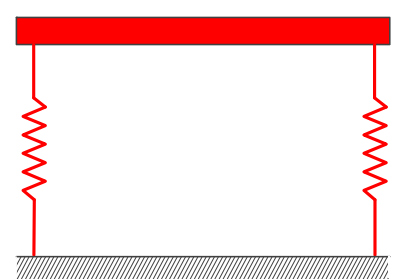

(a)

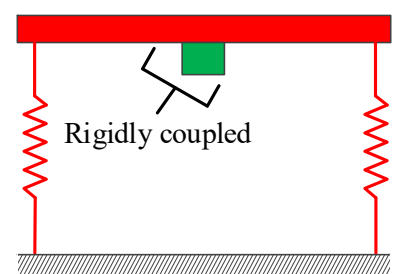

(b)

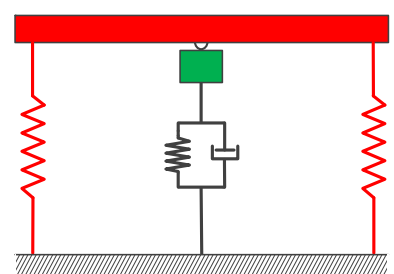

(c)

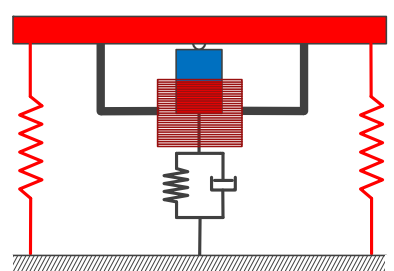

(d)

Fig. 6 Four kinds of analytical models used in the simulations: (a) only host structure, (b) host structure with additional mass, (c) conventional method, and (d) proposed method. For simplicity, the spring and dashpot that support the impact damper were ignored in the simulations.

\section{4-2 4 つのモデルのシミュレーション結果}

表 1 にシミュレーションで用いた諸元を, 図 7 に 4 つのモデルの主系の変位 $x_{1}$ と速度 $\dot{x}_{1}$, および提案手法の電 磁力 $-f_{\mathrm{C}}$ と電流 $\dot{q}$ のシミュレーションの結果をそれぞれ示す.ここで, 電磁力をー $f_{\mathrm{C}}$ とた理由は, 主系に対し て上向きに加わる電磁力は- $f_{\mathrm{C}}$ であるためである. また， $q(0)$ はコンデンサの初期電荷であり, $q(0)=C_{3} V_{\mathrm{DC}}$ で ある. なお，提案手法において電流がゼロになった時刻は 0.0465 秒であり，このとき主系の速度もゼロとなるよ 
うに静電容量の值を選んだ。図 7 より従来型に比べて電磁石を用いた運動量交換型衝撃吸収ダンパでは主系の最 大変位および速度が従来型に比べて大きく低減できており，提案手法の有効性が確認できる. このときの主系の 初期運動量 $F_{1}$ は- $0.41 \mathrm{Ns}$, 電磁力が主系に与えた力積 $F_{3}$ は $0.33 \mathrm{Ns}$ である. また, このときの主系の初期運動工 ネルギ $E_{1}$ は $0.0134 \mathrm{~J}$, 電磁力が主系から吸収したエネルギ $E_{3}$ は $0.0115 \mathrm{~J}$ である. なお, 主系の固有振動数は約 2.5 $\mathrm{Hz}, \mathrm{LC}$ 回路の固有振動数は約 $14 \mathrm{~Hz}$ であった.

つぎに, 電気系の固有振動数を変えることにより, 主系の運動エネルギを短時間で吸収する場合と相対的に長 い時間をかけて吸収する場合の衝撃低減効果を比較するためのシミュレーションを行った．図 8 にコンデンサの 静電容量 $C_{3}$ とコイルのインダクタンス $L_{3}$ の組合せを, $C_{3}=1.55[\mathrm{mF}]$ かつ $L_{3}=500[\mathrm{mH}], C_{3}=4[\mathrm{mF}]$ かつ $L_{3}=100[\mathrm{mH}], C_{3}=10[\mathrm{mF}]$ かつ $L_{3}=3[\mathrm{mH}]$ と変えた場合の主系の変位 $x_{1}$ と速度 $\dot{x}_{1}$, および提案手法の電磁力 $-f_{\mathrm{C}}$ と電流 $\dot{q}$ のシミュレーションの結果をそれぞれ示す.ただし，ここではソレノイドコイルの巻き数は変えず に仮想的にソレノイドコイルのインダクタンスのみ変更した. また, 表 2 に電磁力が主系に与えた力積 $F_{3}$, 電磁 力が吸収したエネルギ $E_{3}$ を示す. 表 2 には $\left|F_{3} / F_{1}\right|$ で定義される力積の割合と， $E_{3} / E_{1}$ で定義される吸収したエネ ルギの割合も付記した. 図 8, 表 2 より, $C_{3}=10[\mathrm{mF}]$ かつ $L_{3}=3[\mathrm{mH}], C_{3}=4[\mathrm{mF}]$ かつ $L_{3}=100[\mathrm{mH}]$,

Table 1 Material properties used in the simulations.

\begin{tabular}{c|rl|r|rl}
\hline \hline$m_{1}$ & 6.28 & $\mathrm{~kg}$ & $N$ & 300 & \\
\hline$m_{2}$ & 0.27 & $\mathrm{~kg}$ & $l$ & 36 & $\mathrm{~mm}$ \\
\hline$F_{\mathrm{m}}$ & -0.45 & $\mathrm{Ns}$ & $C_{3}$ & 5.1 & $\mathrm{mF}$ \\
\hline$k_{1}$ & 1580 & $\mathrm{~N} / \mathrm{m}$ & $L_{3}$ & 50 & $\mathrm{mH}$ \\
\hline$V_{\mathrm{DC}}$ & 15 & $\mathrm{~V}$ & $\sigma$ & 340 & $\mu \mathrm{Wb}$ \\
\hline$R_{3}$ & 0.5 & $\Omega$ & $\alpha$ & 2.83 & $\mathrm{~Wb} / \mathrm{m}$ \\
\hline$q(0)$ & 0.0765 & $\mathrm{C}$ & - & - & - \\
\hline
\end{tabular}
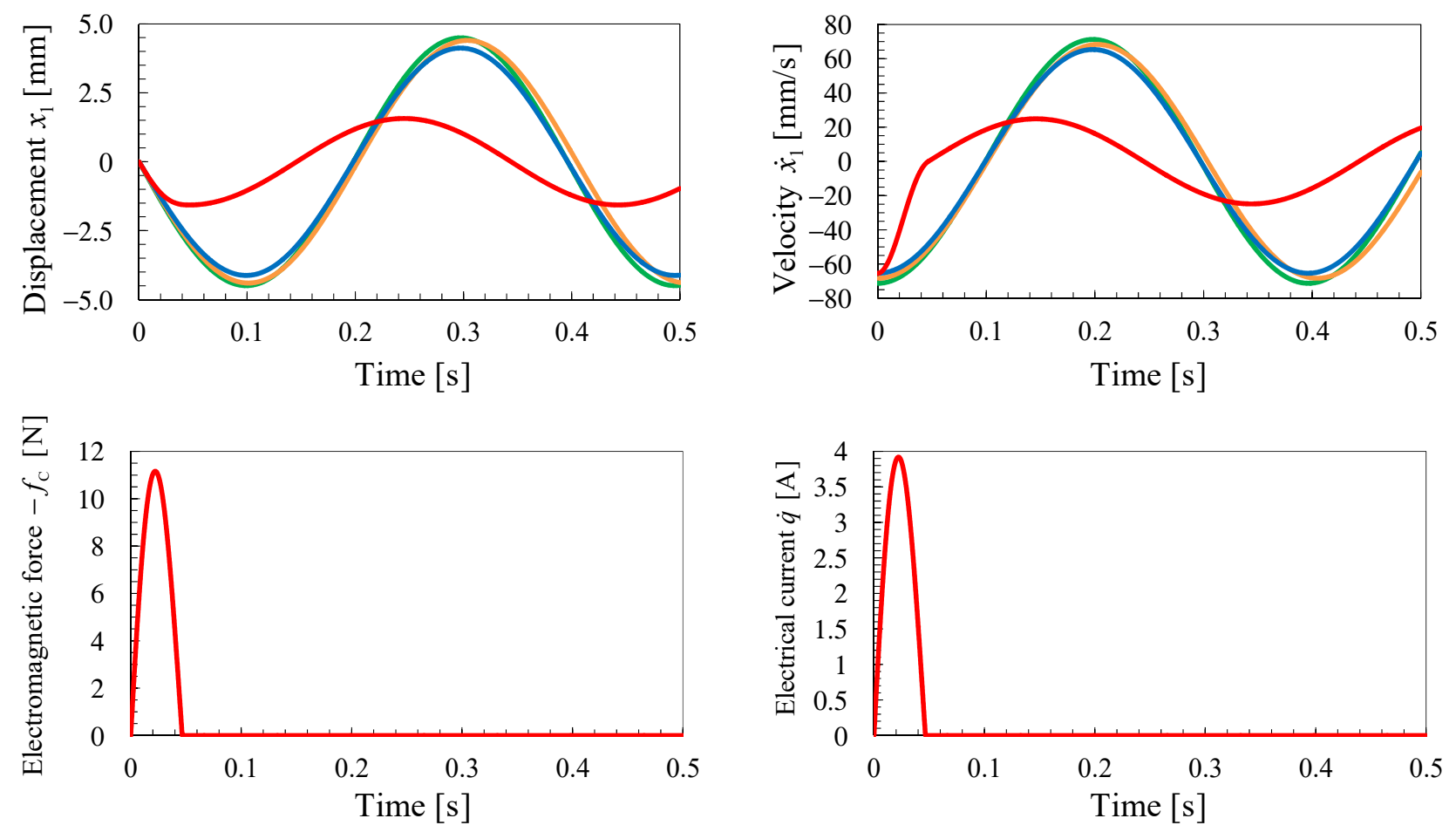

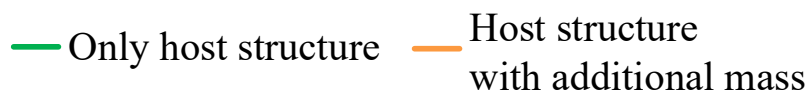

- Conventional method — Proposed method

Fig. 7 Simulation results of the displacement and velocity of the host structure, and the electromagnetic force and electrical current. The four kinds of analytical models shown in Fig. 6 were compared. 

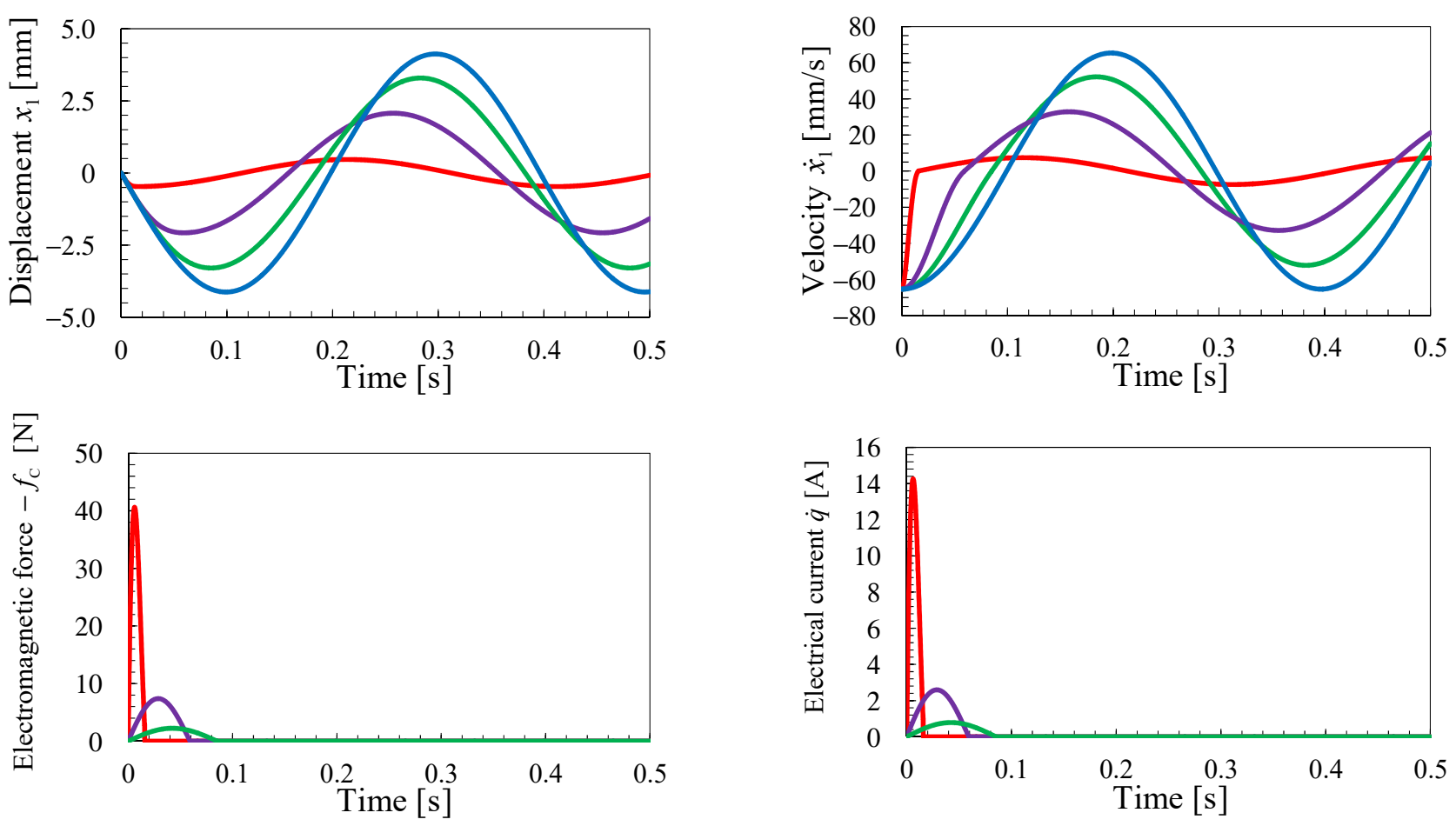

- Conventional method

$-C_{3}=4[\mathrm{mF}], L_{3}=100[\mathrm{mH}]$

$$
\begin{aligned}
& -C_{3}=1.55[\mathrm{mF}], L_{3}=500[\mathrm{mH}] \\
& -C_{3}=10[\mathrm{mF}], L_{3}=3[\mathrm{mH}]
\end{aligned}
$$

Fig. 8 Simulation results of the displacement and velocity of the host structure, and the electromagnetic force and electrical current using different values of the natural frequency of the LC circuit. The case of $C_{3}=10[\mathrm{mF}], L_{3}=3[\mathrm{mH}]$ is the most effective because the kinetic energy of the host structure was absorbed for a short time.

Table 2 Absorbed momentum and kinetic energy in the simulations using different values of the natural frequency of the LC circuit.

\begin{tabular}{c|c|c|c}
\hline \hline & $C_{3}=1.55[\mathrm{mF}], L_{3}=500[\mathrm{mH}]$ & $C_{3}=4[\mathrm{mF}], L_{3}=100[\mathrm{mH}]$ & $C_{3}=10[\mathrm{mF}], L_{3}=3[\mathrm{mH}]$ \\
\hline$F_{3}(\mathrm{~N} \mathrm{~s})$ & 0.12 & 0.28 & 0.40 \\
$\left(\mid F_{3} / F_{1} \%\right)$ & $(30 \%)$ & $(68 \%)$ & $(98 \%)$ \\
\hline$E_{3}(\mathrm{~J})$ & 0.0049 & 0.010 & 0.013 \\
$\left(E_{3} / E_{1} \%\right)$ & $(36 \%)$ & $(75 \%)$ & $(99 \%)$ \\
\hline
\end{tabular}

$C_{3}=1.55[\mathrm{mF}]$ かつ $L_{3}=500[\mathrm{mH}]$ の順に制振性能が良いことが分かる. $C_{3}=10[\mathrm{mF}], L_{3}=3[\mathrm{mH}]$ の場合は短時 間で主系の運動エネルギを吸収して衝撃を抑えており，電磁力は運動量の交換を促進していると言える. $C_{3}=4[\mathrm{mF}]$ かつ $L_{3}=100[\mathrm{mH}]$ や $C_{3}=1.55[\mathrm{mF}]$ かつ $L_{3}=500[\mathrm{mH}]$ の場合は, 相対的に長い時間をかけて主系の 運動エネルギを吸収している。このとき，残りのエネルギは主系のばねに蓄えられるため，吸収できるエネルギ の割合が低下する.

\section{5. 実 験}

\section{$5 \cdot 1$ 実験装置と測定方法}

表 3 に実験装置の諸元を, 図 9 に実験装置の全体の写真を示す. 制振対象は厚さ $20 \mathrm{~mm}$ アルニウムの板であ り，その四隅にはガイドとして丸材を通した。四本のガイド用の丸棒には主系を支持するばねを設置した。眓 9 に示すように，ネオジム磁石を衝撃吸収ダンパ用の質点として制振対象である主系の下部に面で接するように設 置した。また，ネオジム磁石の下側を十分にやわらかいばねで支持した．ただし，簡単のためダッシュポットに 
相当する減衰機構は付加しなかった。 また，アクリルパイプに線径 $1.2 \mathrm{~mm}$ のポリエステルエナメル銅線を 300 回巻きしたソレノイドコイルを主系に剛結合した．主系の変位はレーザ変位計（キーエンス製センサヘッド LB-300，アンプ LB-1200，サンプリング周波数 $915 \mathrm{~Hz}$ ）を，主系の速度はレーザドップラ振動計（電子技研工業 製V100-MS TYPE-D，サンプリング周波数 $100 \mathrm{kHz}$ ）を用いて測定し，データはFFT アナライザを用いて $256 \mathrm{~Hz}$ のサンプリング周波数で記録した. 衝撃は野球の硬球によって与えた. ここで, 跳䘤ったボールは手で受止め て二度目の衝突を防いだ. 主系に与えた力積は, ボールの質量, 初期高さ, 跳衫返り高さより力学的に求めた.

図 10 に実験で用いた回路図を示す. スイッチ 1 は直流電源を用いてコンデンサに電荷を蓄える役割であり,ソレ ノイドコイルに電流を流すためのスイッチとして逆阻止三端子サイリスタ（ルネサスエレクトロニクス製 CR25

Table 3 Material properties of the experimental apparatus.

\begin{tabular}{c|rl|r|r|r|rc}
\hline \hline$m_{1}$ & $6.28 \mathrm{~kg}$ & $N$ & 300 & $\sigma$ & 340 & $\mu \mathrm{Wb}$ \\
\hline$m_{2}$ & $0.27 \mathrm{~kg}$ & $l$ & $36 \mathrm{~mm}$ & $q(0)$ & 0.11 & $\mathrm{C}$ \\
\hline$F_{\mathrm{m}}$ & $-0.62 \mathrm{Ns}$ & $L_{3}$ & $5.1 \mathrm{mH}$ & $V_{\mathrm{DC}}$ & 15 & $\mathrm{~V}$ \\
\hline$k_{1}$ & $1580 \mathrm{~N} / \mathrm{m}$ & $R_{3}$ & $1.75 \Omega$ & $\alpha$ & 2.83 & $\mathrm{~Wb} / \mathrm{m}$ \\
\hline$k_{2}$ & $98 \mathrm{~N} / \mathrm{m}$ & $C_{3}$ & $7.1 \mathrm{mF}$ & - & - & - \\
\hline
\end{tabular}

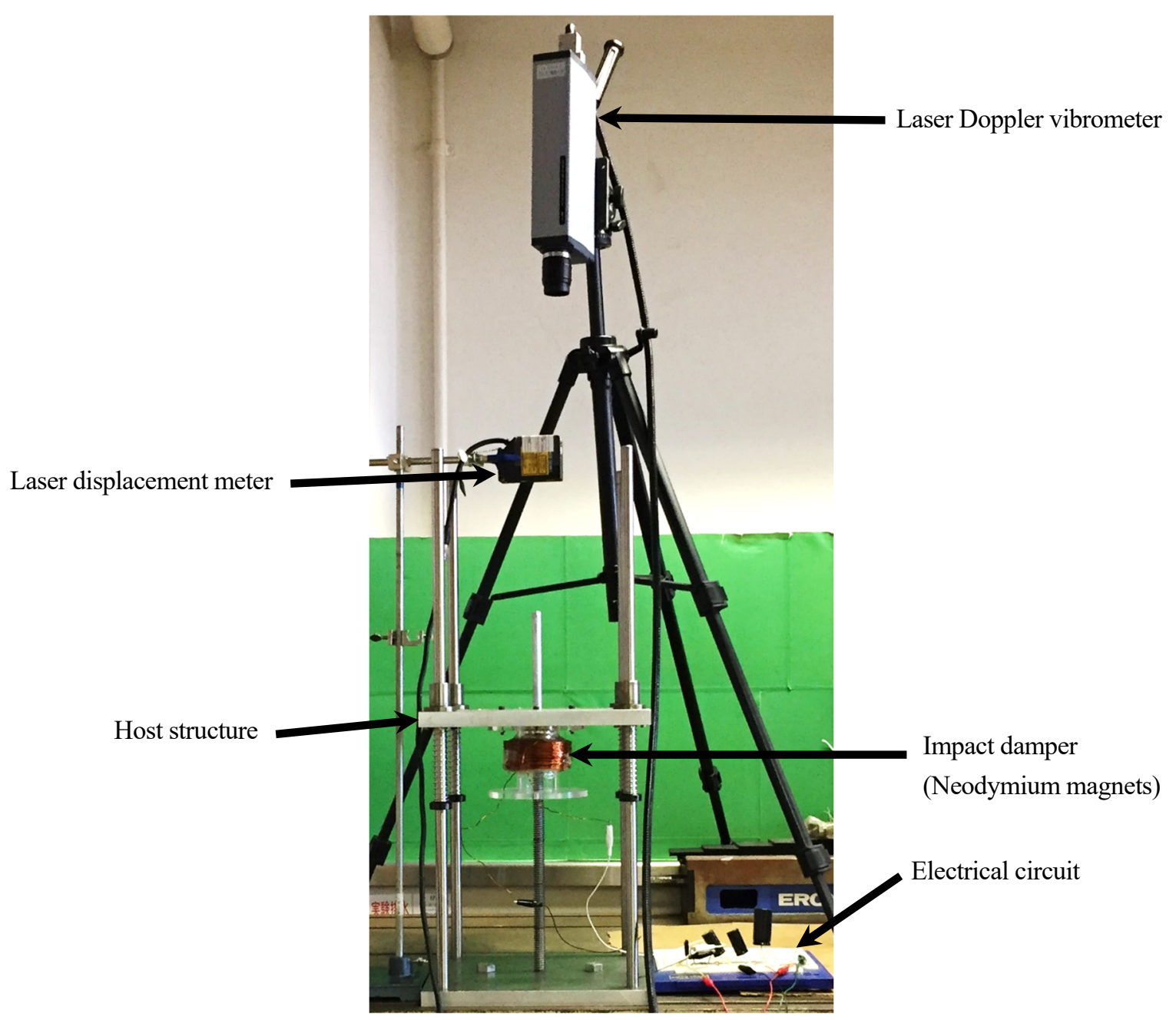

Fig. 9 Picture of the experimental apparatus. The combination of six neodymium magnets was used as the impact damper. The acrylic pipe of the solenoidal coil was rigidly coupled to the host structure. The host structure was excited by the drop of a hardball. The displacement of the host structure was measured using the laser displacement meter. The velocity of the host structure was measured using the laser Doppler vibrometer. 


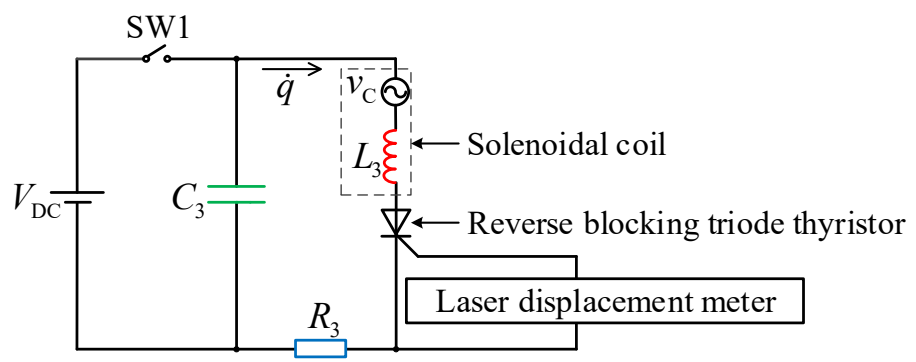

Fig. 10 Circuit diagram of the electrical circuit coupled to the solenoidal coil in the experiment. The electrical charge stored in the capacitor flows through the solenoidal coil when the impact damper passes through the solenoidal coil using the reverse blocking triode thyristor.

RM-12D）を用いた．主系の変位を測定中のレーザ変位計からサイリスタのゲートに約 $11 \mathrm{~mA}$ 以上の電流を流す ことで，アノードとカソード間が導通し，そのままソレノイドコイルに電流が一方向にのみ流れ続ける回路であ る、サイリスタはダイオードの一種であるため，逆流を防ぐ役割も果たすことができる．ただし，表 3 のソレノ イドコイルとコンデンサの内部抵抗を合わせた抵抗值 $R_{3}$ は $26 \mathrm{~Hz}$ で測定した值である. $26 \mathrm{~Hz}$ は電気系の固有振 動数である.

\section{$5 \cdot 2$ 実験とシミュレーションの結果の比較}

図 11 に主系の変位 $x_{1}$ の実験結果と, 実験装置の諸元を用いて行ったシミュレーションの結果を, 図 12 に主系 の速度 $\dot{x}_{1}$ の実験結果と, 実験装置の諸元を用いて行ったシミュレーションの結果をそれぞれ示す. 実験結果，シ ミュレーション結果ともに，主系のみの場合，主系の質量を衝撃吸収ダンパの質量分だけ増やした場合，従来の 運動量交換型衝撃吸収ダンパの場合(門馬他，2002; 河内他，2004; Son et al., 2006, 2008), 提案手法の場合で比較 した.シミュレーションで電流值がゼロになった時刻は 0.044 秒である. 実験とシミュレーションの結果より， 提案手法は従来の運動量交換型衝撃吸収ダンパより変位を低減できており，提案手法の有効性を確認できる。し かし, シミュレーションよりも実験結果の振動低減効果が低くなっている.これはサイリスタの内部抵抗を考慮 しなかったことが原因と考え， $R_{3}$ を仮に $5 \Omega$ に増やしてシミュレーションを行った. その結果を図 13 に示す. $R_{3}$ を $5 \Omega$ に増やすと実験とシミュレーションの結果がよく合った. 図 14 にサイリスタ単体に印加した定電圧 $V$ 卡， その時に流れる定電流 $I$ の実測結果を示す. 図 14 よりサイリスタの電圧-電流特性は指数関数的に变化しており, その近似式は

$$
I=8 \times 10^{-5} \exp \left(8 V_{\mathrm{t}}\right)
$$

となる(一番ヶ瀬, 2007). 図 15 に式(32)より求まるサイリスタの電流 $\dot{q}$ と内部抵抗の抵抗值 $R_{\mathrm{t}}$ の関係を示す. 式 (32), 図 15 より, 電流が $0.4 \mathrm{~A}$ の時のサイリスタの内部抵抗が約 $3.25 \Omega$ であり, サイリスタの内部抵抗の分だけ $R_{3}$ が大きくなったという考察は妥当であると考えられる.

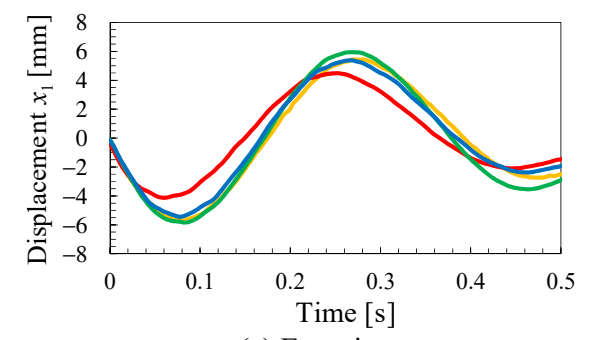

(a) Experiment

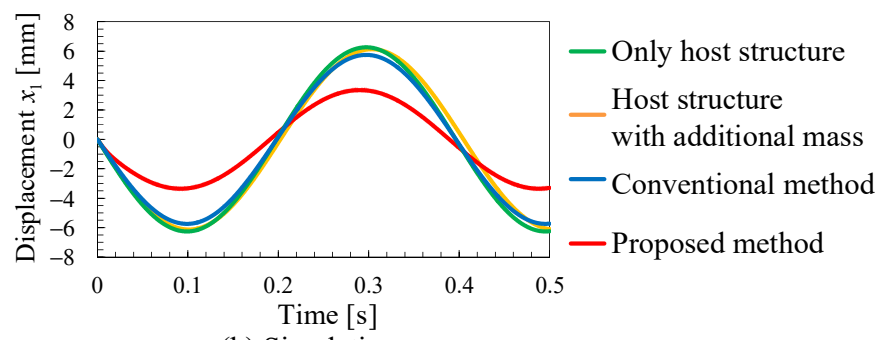

(b) Simulation

Fig. 11 Comparison of the experimental and simulation results of the displacement of the host structure. The four kinds of the models were compared. 


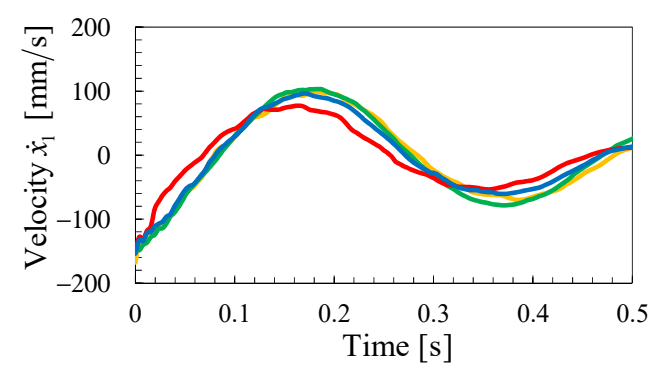

(a) Experiment

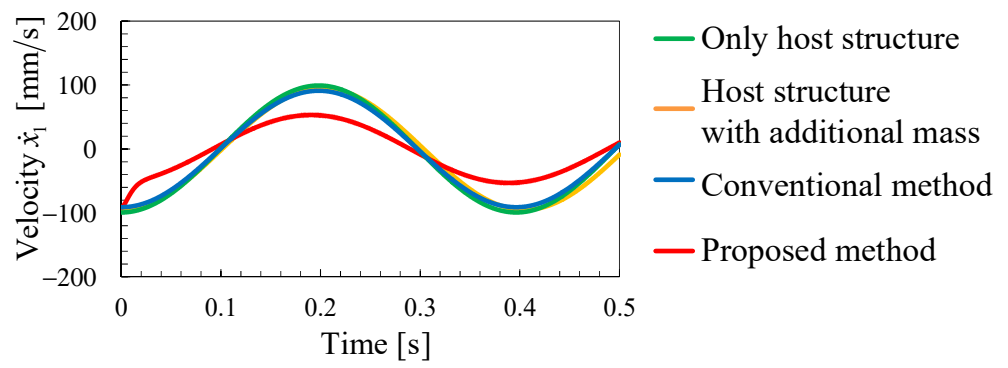

(b) Simulation

Fig. 12 Comparison of the experimental and simulation results of the velocity of the host structure. The four kinds of the models were compared.
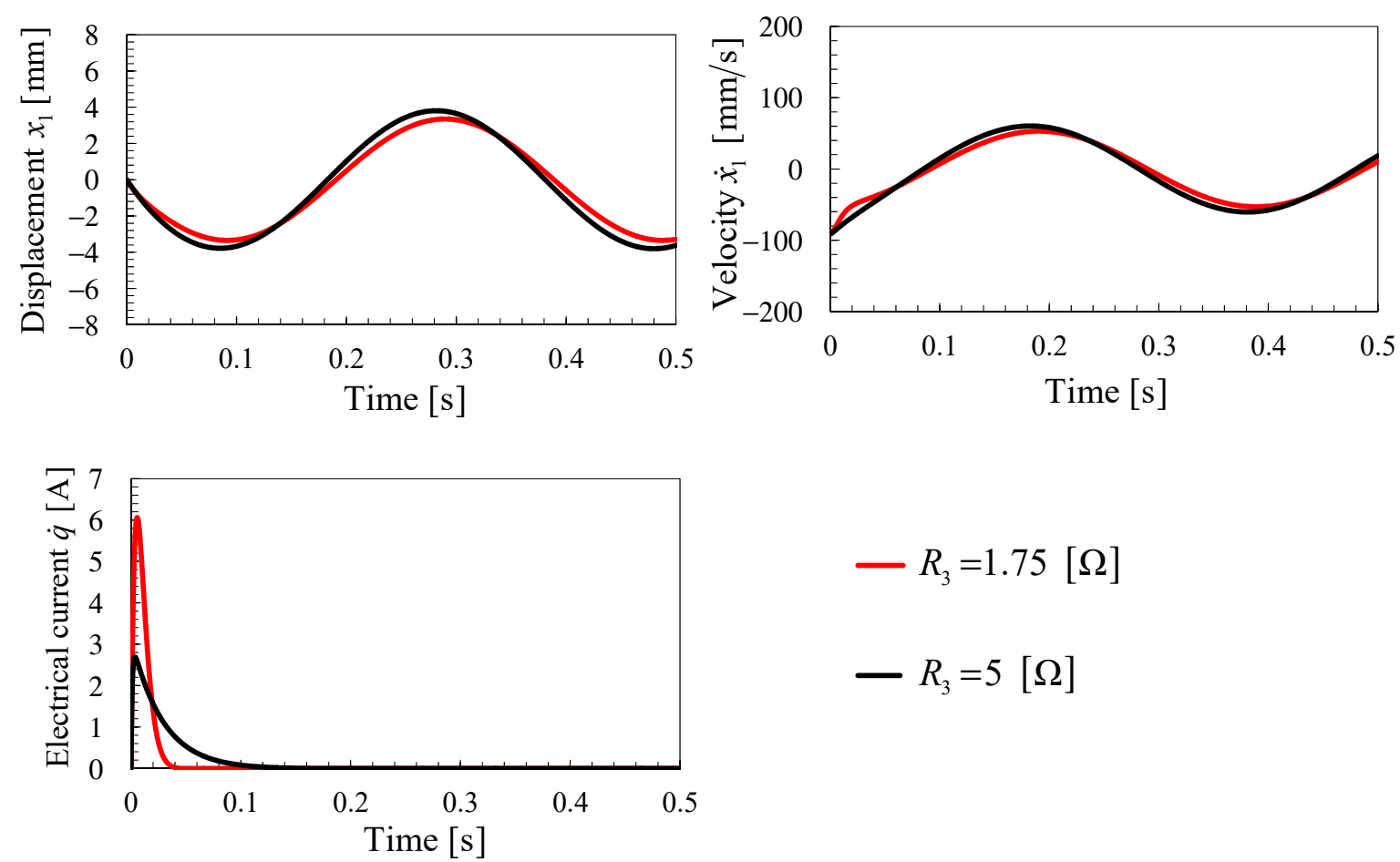

Fig. 13 Simulation results of the displacement and velocity of the host structure, and simulation result of the electrical current of the proposed method using different values of the internal resistance of the solenoidal coil and capacitor. The simulation result using $R_{3}=5[\Omega]$ agrees well with the experimental result.

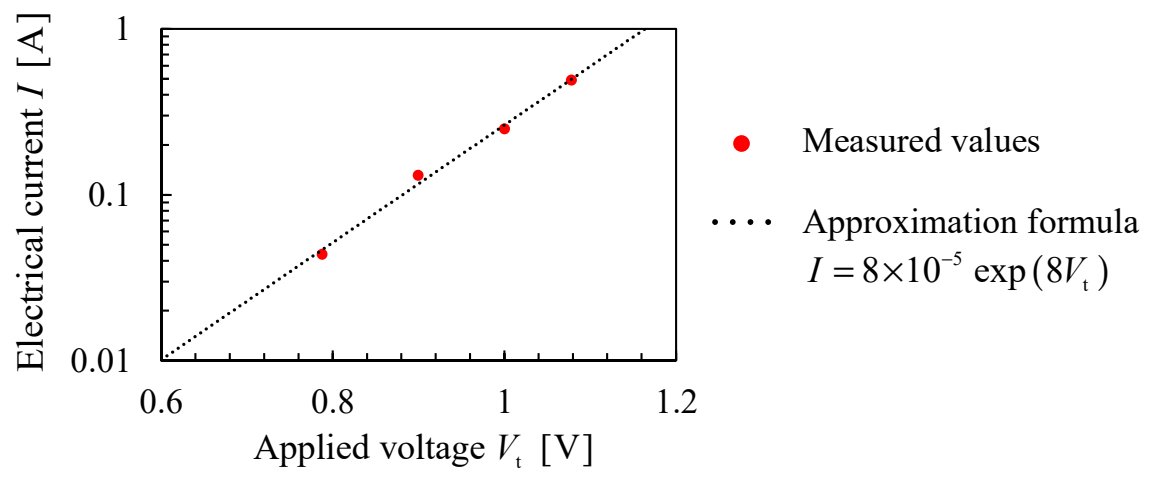

Fig. 14 Measured values and approximation formula of the voltage-current characteristic of the thyristor used in the experiment. 


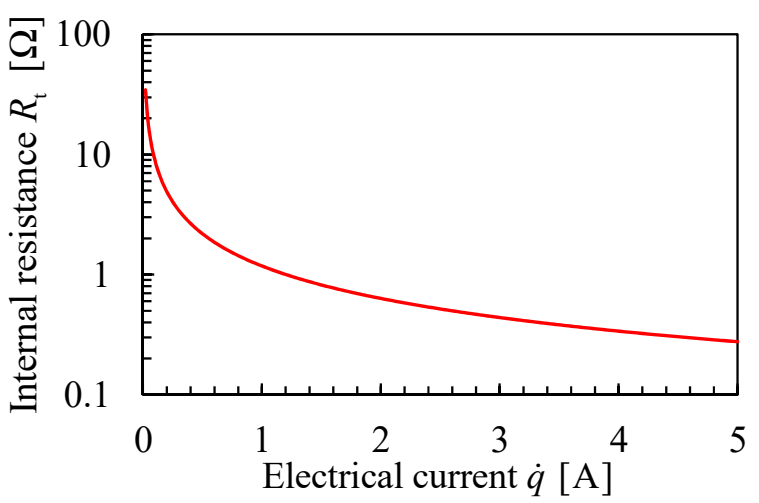

Fig. 15 Internal resistance of the thyristor using Eq. (32). The internal resistance depends on the value of the electrical current.

\section{6. 結 言}

本研究では，電磁石とコンデンサを組込んだ運動量交換型衝撃吸収ダンパを提案した。そして，ソレノイドコ イルにおける電磁石の電磁力と誘導起電力の式を理論的に導出した。 また，理論解析に基づいたシミュレーショ ンにより，提案手法で受動型よりも高い衝撃低減効果が得られることを確認した。また，インダクタンスと静電 容量で決まる電気系の固有振動数を十分に高く設定し，運動量の交換を短時間で行うと運動量交換が促進される ことを示した．実験においては回路内の内部抵抗で制振性能が低下寸ることが分かったが，それでも提案手法で は受動型の運動量交換型衝撃吸収ダンパよりも高い振動低減効果が得られ，提案手法の有効性が確認できた。 な お，本研究ではサイリスタにスイッチと逆流阻止のダイオードを兼ねさせたため，レーザ変位計で主系の変位を 測定したが，コイルガンと同様に機械的な機構でスイッチをオンにすることも可能であり，その場合は電荷の蓄 積以外は受動的な装置となる. 提案した方法は能動制振の一種ではあるが, ディジタルコントローラを用いた能 動制振に比べると，装置が簡易であるという長所がある.

\section{謝辞}

本研究は科学研究費補助金基盤研究（A）（課題番号 26249023）の助成を受けたことを付記し，謝意を表する.

\section{文献}

Ceanga, V. and Hurmuzlu, Y., A new look at an old problem: Newtons Cradle, ASME Journal of Applied Mechanics, Vol. 68, No. 4 (2001), pp. 575-583.

原進，渡辺翼，櫛田陽平，大槻真嗣，山田陽滋，松久寛，山田啓介，橋本樹明，久保田孝，運動量交換原理に基 づた惑星探査機の着陸応答制御の研究，日本機械学会論文集 C 編，Vol. 78，No. 792 (2012), pp. 62-77.

一番ヶ瀬剛, II - VI族化合物半導体 ZnSe 基板の ITO との電気特性, 電学論 E, Vol. 127, No. 4 (2007), pp. 234-240. 河内誠, 松久寛, 宇津野秀夫, 朴正圭, 運動量交換型衝撃吸収ダンパによる床の重量衝撃緩和, Dynamics and Design Conference (2004), CD-ROM 129.

門馬雅高, 朴正圭, 松久寛, 藩公宇, 安田正志, 床の重量衝撃吸収に関する研究, Dynamics and Design Conference (2002), CD-ROM 529.

Son, L., Hara, S., Yamada, K. and Matsuhisa, H., Experiment of shock vibration control using active momentum exchange impact damper, Journal of Vibration and Control, Vol. 16, No. 1 (2010), pp. 49-64.

Son, L., Matsuhisa, H. and Utsuno, H., Energy transfer in a three body momentum exchange impact damper, Journal of System Design and Dynamics, Vol. 2, No. 1 (2008), pp. 425-441.

Son, L., Nakatani, D., Matsuhisa, H. and Utsuno, H., Application of momentum exchange impact dampers to forging machine, Journal of System Design and Dynamics, Vol. 2, No. 4 (2006), pp. 1027-1039.

砂川重信, 電磁気学 (1987), 岩波書店. 
高橋喜久雄, 電気磁気学原論 (1965), 昭晃堂.

竹山説三, 電磁気学現象論 (1944), 丸善.

Tanaka, N. and Kikushima, Y., A study of a servodamper with preview action (an optimal design for impact vibration control), JSME International Journal, Series 3, Vol. 32, No. 2 (1989), pp. 215-222.

Webster, A. C. and Vaicaitis, R., Application of tuned mass dampers to control vibrations of composite floor systems, Engineering Journal of AISC, Vol. 29, No. 3 (1992), pp. 116-124.

\section{References}

Ceanga, V. and Hurmuzlu, Y., A new look at an old problem: Newtons Cradle, ASME Journal of Applied Mechanics, Vol. 68, No. 4 (2001), pp. 575-583.

Hara, S., Watanabe, T., Kushida, Y., Otsuki, M., Yamada, Y., Matsuhisa, H., Yamada, K., Hashimoto, T. and Kubota, T., Study on landing response control of planetary exploration spacecraft based on momentum exchange principles, Transactions of the Japan Society of Mechanical Engineers, Series C, Vol. 78, No. 792 (2012), pp. $62-77$ (in Japanese).

Ichibankase, T., Transport properties of ZnSe-ITO hetero junction, The Institute of Electrical Engineers of Japan E, Vol. 127, No. 4 (2007), pp. 234-240 (in Japanese).

Kawachi, M., Matsuhisa, H., Utsuno, H. and Park, J., Reduction of floor heavy impact by a momentum exchanging damper, Dynamics and Design Conference (2004), CD-ROM 129 (in Japanese).

Momma, M., Park, J., Matsuhisa, H., Pan, G. and Yasuda, M., On the study of impact absorption of the floor, Dynamics and Design Conference (2002), CD-ROM 529 (in Japanese).

Son, L., Hara, S., Yamada, K. and Matsuhisa, H., Experiment of shock vibration control using active momentum exchange impact damper, Journal of Vibration and Control, Vol. 16, No. 1 (2010), pp. 49-64.

Son, L., Matsuhisa, H. and Utsuno, H., Energy transfer in a three body momentum exchange impact damper, Journal of System Design and Dynamics, Vol. 2, No. 1 (2008), pp. 425-441.

Son, L., Nakatani, D., Matsuhisa, H. and Utsuno, H., Application of momentum exchange impact dampers to forging machine, Journal of System Design and Dynamics, Vol. 2, No. 4 (2006), pp. 1027-1039.

Sunakawa, S., Electromagnetism (1987), Iwanami Shoten Publishing (in Japanese).

Takahashi, K., Electromagnetics principles (1965), Shokodo Publishing (in Japanese).

Takeyama, S., Electromagnetism phenomenological (1944), Maruzen Publishing (in Japanese).

Tanaka, N. and Kikushima, Y., A study of a servodamper with preview action (an optimal design for impact vibration control), JSME International Journal, Series 3, Vol. 32, No. 2 (1989), pp. 215-222.

Webster, A. C. and Vaicaitis, R., Application of tuned mass dampers to control vibrations of composite floor systems, Engineering Journal of AISC, Vol. 29, No. 3 (1992), pp. 116-124. 